\title{
Effect of statin therapy on vaspin levels in type 2 diabetic patients
}

This article was published in the following Dove Press journal:

Clinical Pharmacology:Advances and Applications

19 February 2013

Number of times this article has been viewed

\author{
Sayer I Al-Azzam' \\ Karem H Alzoubi' \\ Jaafar Abu Abeeleh² \\ Nizar M Mhaidat' \\ Mahmoud Abu-Abeeleh ${ }^{3}$ \\ 'Department of Clinical Pharmacy, \\ Faculty of Pharmacy, Jordan \\ University of Science and Technology, \\ Irbid, '2Department of Pharmacy, \\ Royal Medical Services, Amman, \\ ${ }^{3}$ Department of Surgery, Division \\ of Cardiothoracic Surgery, Faculty \\ of Medicine, The University \\ of Jordan, Amman, Jordan
}

Background: Statins are commonly used antihyperlipidemic agents, with anti-inflammatory and immunomodulatory properties that are thought to account for a significant portion of their ability to protect against atherosclerosis and cardiovascular disease. Vaspin, a visceral adipose tissue-derived serine protease inhibitor, is an emerging adipokine with important insulinsensitizing, cardioprotective, and antiatherosclerotic properties in patients with diabetes. In this randomized controlled clinical trial, we evaluated the effect of statin therapy on vaspin levels in patients with type 2 diabetes mellitus.

Methods: Patients were divided into two groups, ie, those receiving simvastatin (study group, $\mathrm{n}=33$ ), and those who did not (control group, $\mathrm{n}=29$ ). Patient data, blood biochemistry, and vaspin levels were recorded at the beginning of the study (baseline) and after 8 weeks (end of the study).

Results: After 8 weeks of treatment, vaspin levels were increased in patients treated with simvas$\operatorname{tatin}(504.58 \pm 203.07 \mathrm{pg} / \mathrm{mL}$ at baseline versus $629.15 \pm 68.39 \mathrm{pg} / \mathrm{mL}$ after 8 weeks, $P<0.01)$, but not in patients who were not treated with simvastatin $(613.33 \pm 357.53 \mathrm{pg} / \mathrm{mL}$ at baseline versus $582.37 \pm 84.63 \mathrm{pg} / \mathrm{mL}$ after 8 weeks, $P>0.05$ ). In addition, the lipid-lowering effect of simvastatin was reflected in a statistically significant reduction in total cholesterol in the study group $(220.75 \pm 55.66 \mathrm{mg} / \mathrm{dL}$ at baseline versus $201.90 \pm 53.65 \mathrm{mg} / \mathrm{dL}$ after 8 weeks $P<0.01)$ but not in the control group $(214.24 \pm 47.2 \mathrm{mg} / \mathrm{dL}$ at baseline versus $215.72 \pm 43.65 \mathrm{mg} / \mathrm{dL}$ after 8 weeks, $P>0.05$ ) and in a statistically significant reduction in triglyceride levels in the study group $(265.8 \pm 210.41 \mathrm{mg} / \mathrm{dL}$ at baseline versus $223.03 \pm 178.67 \mathrm{mg} / \mathrm{dL}$ after 8 weeks, $P<0.05$ ) but not in the control group $(225.44 \pm 115.13 \mathrm{mg} / \mathrm{dL}$ at baseline versus $215.58 \pm 110.2 \mathrm{mg} / \mathrm{dL}$ after 8 weeks, $P>0.05$ ). Mean vaspin levels were significantly higher in the study group than in the control group.

Conclusion: These results indicate that statin therapy increases plasma vaspin levels in addition to having a lipid-lowering effect. This could be a mechanism underlying the pleiotropic effects seen with statins, including their cardioprotective and antiatherosclerotic effects.

Keywords: vaspin, statins, diabetes, adipokines

\section{Introduction}

Statins are the most widely used lipid-lowering agents. They reduce lipid levels in patients with dyslipidemia and the risk of cardiovascular disease and atherosclerosis, and also reduce morbidity and mortality in patients with and without cardiovascular disease. ${ }^{1,2}$ Statins exert their hypolipidemic effect by inhibiting the 3-hydroxy-3methylglutaryl coenzyme A reductase enzyme, which catalyzes the rate-limiting step in the synthesis of cholesterol. ${ }^{3}$
Correspondence: Sayer I Al-Azzam Department of Clinical Pharmacy, Faculty of Pharmacy, Jordan University of Science and Technology, PO Box 3030, Irbid 22I I0, Jordan Tel +96227201000 ext 2344l Fax +96227201075

Email sayerazzam@yahoo.com which permits unrestricted noncommercial use, provided the original work is properly cited. 
Statins also have anti-inflammatory and immunomodulatory properties, ${ }^{4}$ and have been shown to decrease the serum levels of many proinflammatory cytokines, including C-reactive protein, tumor necrosis factor- $\alpha$, and interleukin- 6 , with variable results reported for tumor necrosis factor- $\alpha$ and interleukin-6. ${ }^{5,6}$ These anti-inflammatory effects may explain the reduction in atherosclerosis and cardiovascular disease observed with statins independent of their cholesterol-lowering properties. ${ }^{7}$ The anti-inflammatory effects of statins also have a positive effect on insulin resistance in obesity. ${ }^{8,9}$ Studies have shown that inflammatory pathways are critical in the link between insulin resistance and obesity. ${ }^{10,11}$ Adipocytes are usually enlarged in obese individuals, and are characterized by increased expression of proinflammatory adipokines. ${ }^{12}$

A novel adipokine is the visceral adipose tissue-derived serine protease inhibitor, vaspin, which possesses insulinsensitizing activity similar to that of adiponectin. ${ }^{13}$ Vaspin mRNA expression was significantly increased in patients with obesity and insulin resistance. ${ }^{14}$ However, vaspin was also found to improve glucose tolerance and insulin sensitivity in obese rodents and may also normalize altered expression of genes relevant to insulin resistance. ${ }^{14}$ Increased vaspin expression may be an intrinsic compensatory mechanism in adipose tissue as a response to decreased insulin sensitivity or impairment of glucose metabolism. ${ }^{14}$ Vaspin levels were found to have an inverse relationship with the risk of cardiovascular events, suggesting a protective role of vaspin in the pathophysiology of coronary atherosclerosis. ${ }^{15}$ In this study, we aimed to investigate the effect of statin therapy on vaspin levels in patients with type 2 diabetes mellitus.

\section{Materials and methods \\ Subjects and study design}

This randomized clinical study was conducted between January 2011 and March 2011. Participants were considered eligible if they had type 2 diabetes and were aged 18 years or older. Exclusion criteria were the presence of liver disease, type 1 diabetes, elevation of transaminase levels $>1.5$ times the upper limit of normal at baseline, elevation of creatine kinase $>1.5$ times the upper limit of normal at baseline, presence of atrioventricular block and/or sinus bradycardia, presence of acute or chronic renal failure, evidence of electrolyte disturbance, acute cerebrovascular disease or myocardial infarction within the preceding 3 months, evidence of alcohol abuse, hypothyroidism, myopathy, pregnancy, any medication changes during the 2 months preceding participation in the study, and treatment with antihyperlipidemic drugs during the 4 weeks before entering the study. Approval of the institutional review board at the Jordan University of Science and Technology was obtained for this study. Approval was also obtained from the Royal Medical Services to conduct the study at Prince Rashed Hospital.

A total of 62 patients with diabetes were recruited, and randomly assigned to receive simvastatin $20 \mathrm{mg} /$ day (study group, $n=33$ ) or no statin therapy (control group, $n=29$ ). A customized questionnaire was used for data collection and further statistical analysis. The study procedure and goals were explained to the patients approved for entry into the study, who were then asked to sign a consent form and were interviewed by the researcher.

\section{Data collection and patient interviews}

After interview, the medical profile of each patient was reviewed for further collection and confirmation of patient demographics, clinical history, and current drug regimens. The following information categories were completed for each patient: patient variables, including age, gender, height, weight, and blood pressure (measured at baseline and after 8 weeks); family and medical history and diabetes complications (evaluated according to their complaints, self-evaluation, or past medical reports). Body mass index was calculated as $\mathrm{kg} / \mathrm{m}^{2}$, and patients were classified as normal (18-24.9), overweight (25-29.9), obese (30-34.9), or morbidly obese $(>35){ }^{16}$

\section{Blood biochemistry}

Blood samples were drawn from the participants by a specialized laboratory technician after an overnight fast at baseline and at the end of the study 8 weeks later. A sample was put into an evacuated EDTA tube ( $5 \mathrm{~mL}$ blood) and into an anticoagulant-free plain tube ( $10 \mathrm{~mL}$ blood). The latter was centrifuged at $4000 \mathrm{rpm}$ for 4 minutes. Five hundred microliters of each serum sample was sent for analysis of glucose, triglycerides, total cholesterol, low-density lipoprotein (LDL) cholesterol, high-density lipoprotein (HDL) cholesterol, and creatine kinase levels. The remainder of the serum samples was put into tubes to be used for measurement of vaspin levels with commercially available kits (RayBio ${ }^{\circledR}$ vaspin enzyme immunoassay, RayBiotech Inc, Norcross, GA) according to the manufacturer's instructions. Microplates were read at $450 \mathrm{~nm}$ using an automated reader (ELx800, Bio-Tek Instruments, Winooski, VT).

\section{Statistical analysis}

The data were analyzed using the Statistical Package for the Social Sciences version 17 (SPSS Inc, Chicago, IL). Frequencies, means, and standard deviations were used to 
describe the data whenever appropriate. The Chi-square test or Student's $t$-test were used to test for differences between proportions. $P<0.05$ was considered to be statistically significant.

\section{Results}

\section{Baseline demographics, biochemistry, and clinical characteristics}

There was no statistically significant difference in vaspin levels between the study and control groups at baseline (Table 1). In addition, patient age, body mass index, duration of diabetes, gender, blood pressure, peripheral neuropathy, and family history of cardiovascular disease, thyroid disease, diabetes, diabetic foot ulcer, heart disease, nephropathy, erectile dysfunction, and dyslipidemia were not significantly

Table I Baseline characteristics of study and control groups

\begin{tabular}{|c|c|c|c|}
\hline \multirow[t]{2}{*}{ Variable } & \multicolumn{2}{|l|}{ Mean \pm SD or $\%$} & \multirow[t]{2}{*}{$P$ value } \\
\hline & $\begin{array}{l}\text { Study } \\
\text { group }\end{array}$ & $\begin{array}{l}\text { Control } \\
\text { group }\end{array}$ & \\
\hline Age (years) & $55.34 \pm 13.54$ & $57.06 \pm 10.27$ & 0.52 \\
\hline BMI & $29.36 \pm 5.07$ & $35.71 \pm 29.62$ & 0.26 \\
\hline Duration of DM (years) & $6.74 \pm 5.40$ & $8.63 \pm 6.40$ & 0.19 \\
\hline \multicolumn{4}{|l|}{ Gender } \\
\hline Male & $19(57.6 \%)$ & 14 (48.3\%) & 0.32 \\
\hline Female & $14(42.4 \%)$ & 15 (5I.7\%) & \\
\hline Hypertension & $22(66.6 \%)$ & 14 (48.3\%) & 0.11 \\
\hline Peripheral neuropathy & 25 (75.8\%) & 21 (72.4\%) & 0.49 \\
\hline $\begin{array}{l}\text { Family history of } \\
\text { cardiovascular diseases }\end{array}$ & $8(24.2 \%)$ & $3(10.3)$ & 0.14 \\
\hline $\begin{array}{l}\text { Family history of } \\
\text { thyroid disease }\end{array}$ & $3(9.1 \%)$ & $5(I 7.2)$ & 0.28 \\
\hline $\begin{array}{l}\text { Family history } \\
\text { of diabetes }\end{array}$ & 24 (72.7\%) & 17 (56.6\%) & 0.18 \\
\hline Diabetic foot ulcer & I (3\%) & $4(13.8 \%)$ & 0.13 \\
\hline Heart disease & $0(0 \%)$ & $3(9.1 \%)$ & 0.14 \\
\hline Nephropathy & I (3.4\%) & $0(0 \%)$ & 0.47 \\
\hline Erectile dysfunction & $4(13.8 \%)$ & $9(27.3 \%)$ & 0.16 \\
\hline Dyslipidemia & $15(5 \mid \%)$ & $22(66.7 \%)$ & 0.17 \\
\hline Vaspin (pg/mL) & $504.58 \pm 203.07$ & $613.33 \pm 357.53$ & 0.06 \\
\hline $\mathrm{SBP}(\mathrm{mmHg})$ & $136.0 \pm 18.19$ & $133.80 \pm 18.06$ & 0.69 \\
\hline $\mathrm{DBP}(\mathrm{mmHg})$ & $86.21 \pm 12.18$ & $80.34 \pm 10.13$ & 0.71 \\
\hline Glucose (mg/dL) & $232.75 \pm 76.87$ & $245.86 \pm 94.18$ & 0.41 \\
\hline $\begin{array}{l}\text { Total cholesterol } \\
(\mathrm{mg} / \mathrm{dL})\end{array}$ & $220.75 \pm 55.66$ & $214.24 \pm 47.2$ & 0.42 \\
\hline Triglycerides (mg/dL) & $265.8 \pm 210.41$ & $225.44 \pm 115.13$ & 0.45 \\
\hline $\mathrm{HDL}(\mathrm{mg} / \mathrm{dL})$ & $44.75 \pm 9.48$ & $45.24 \pm|4.5|$ & 0.79 \\
\hline LDL (mg/dL) & $121.63 \pm 42.01$ & $120.06 \pm 38.88$ & 0.70 \\
\hline WBC (mg/dL) & $7.34 \pm 1.58$ & $7.34 \pm 1.58$ & 0.44 \\
\hline CK (mg/dL) & $79.96 \pm 49.86$ & $93.95 \pm 11.21$ & 0.66 \\
\hline
\end{tabular}

Abbreviations: BMI, body mass index; DM, diabetes mellitus; SBP, systolic blood pressure; DBP, diastolic blood pressure; HDL, high-density lipoprotein; LDL, lowdensity lipoprotein; WBC, white blood cells; CK, creatine kinase; SD, standard deviation. different between the study and control groups $(P>0.05)$. There were no significant differences in systolic and diastolic blood pressure, lipid profile, biochemistry, glucose levels, white cell count, and creatine kinase between the study and control groups at baseline.

\section{Biochemistry and clinical characteristics after statin therapy}

Table 2 shows the biochemical parameters in the study and control groups at the end of the study. The mean vaspin level was significantly increased in the study group after treatment with simvastatin $(504.58 \mathrm{pg} / \mathrm{mL}$ at baseline and $629.15 \mathrm{pg} / \mathrm{mL}$ after treatment, $P<0.01$ ), but not in the control group. Of the lipid profile parameters, cholesterol and triglyceride levels changed significantly in the study group. Mean total cholesterol levels decreased from $220.75 \mathrm{mg} / \mathrm{dL}$ at baseline to $201.909 \mathrm{mg} / \mathrm{dL}$ after treatment in the study group $(P=0.01)$, but not in the control group. Mean triglyceride levels decreased significantly from $265.818 \mathrm{mg} / \mathrm{dL}$ at baseline to $223.03 \mathrm{mg} / \mathrm{dL}$ after treatment $(P=0.02)$, but not in the control group. There was no significant difference between the study group and the controls with regard to changes in systolic and diastolic blood pressure, glucose, HDL cholesterol, LDL cholesterol, white cell count, and creatine kinase after treatment.

\section{Change in biochemical parameters in study group versus controls}

The mean vaspin level increased by $124.57 \mathrm{pg} / \mathrm{mL}$ in the study group and decreased by $30.96 \mathrm{pg} / \mathrm{mL}$ in the control group, and the difference was statistically significant $(P=0.015$, Table 3$)$. Mean cholesterol levels decreased by $18.85 \mathrm{mg} / \mathrm{dL}$ in the study group and increased by $1.48 \mathrm{mg} /$ $\mathrm{dL}$ in the control group $(P<0.01)$. A statistically significant difference between these two groups was also found for mean change in tri-glyceride levels $(P<0.01)$, which decreased by $42.79 \mathrm{mg} / \mathrm{dL}$ and $9.86 \mathrm{mg} / \mathrm{dL}$ in the study and control groups, respectively. Mean HDL levels also increased by $2.75 \mathrm{mg} / \mathrm{dL}$ in the study group and decreased by $9.86 \mathrm{mg} / \mathrm{dL}$ in the control group $(P<0.01)$. Mean LDL levels in the study group decreased by $9.12 \mathrm{mg} / \mathrm{dL}$ and increased by $7.96 \mathrm{mg} / \mathrm{dL}$ in the control group. The difference was statistically significant $(P<0.03)$. There was also a significant difference between the two groups for mean systolic blood pressure, which decreased by $2.12 \mathrm{mmHg}$ in the study group compared with a decrease of $0.70 \mathrm{mmHg}$ in the control group $(P<0.01)$. Differences in mean diastolic blood pressure, glucose, white cell count, and creatine kinase 
Table 2 Biochemical parameters and clinical characteristics at baseline and at end of study

\begin{tabular}{|c|c|c|c|c|c|c|}
\hline \multirow[t]{2}{*}{ Variable } & \multicolumn{3}{|c|}{ Study group $(n=33)$} & \multicolumn{3}{|c|}{ Control group $(n=29)$} \\
\hline & $\begin{array}{l}\text { Baseline, } \\
\text { mean } \pm \text { SD }\end{array}$ & $\begin{array}{l}\text { End of treatment, } \\
\text { mean } \pm \text { SD }\end{array}$ & $P$ value & $\begin{array}{l}\text { Baseline, } \\
\text { mean } \pm \text { SD }\end{array}$ & $\begin{array}{l}\text { End of treatment, } \\
\text { mean } \pm \text { SD }\end{array}$ & $P$ value \\
\hline Vaspin (pg/mL) & $504.5 \pm 203.07$ & $629.15 \pm 68.39$ & $<0.01$ & $613.33 \pm 357.53$ & $582.37 \pm 84.63$ & 0.08 \\
\hline $\mathrm{SBP}(\mathrm{mmHg})$ & $136.0 \pm 18.19$ & $133.94 \pm 10.28$ & 0.42 & $133.80 \pm 18.06$ & $133.1 \pm 16.05$ & 0.85 \\
\hline $\mathrm{DBP}(\mathrm{mmHg})$ & $86.21 \pm 12.18$ & $85.15 \pm 9.06$ & 0.66 & $80.34 \pm 10.13$ & $79.31 \pm 10.15$ & 0.69 \\
\hline Glucose (mg/dL) & $232.75 \pm 76.87$ & $221.87 \pm 82.36$ & 0.57 & $245.86 \pm 94.18$ & $234.94 \pm 75.9$ & 0.51 \\
\hline Total cholesterol (mg/dL) & $220.75 \pm 55.66$ & $201.90 \pm 53.65$ & 0.01 & $214.24 \pm 47.2$ & $215.72 \pm 43.65$ & 0.89 \\
\hline Triglycerides (mg/dL) & $265.8 \pm 210.41$ & $223.03 \pm 178.67$ & 0.02 & $225.44 \pm 115.13$ & $215.58 \pm 110.2$ & 0.74 \\
\hline $\mathrm{HDL}(\mathrm{mg} / \mathrm{dL})$ & $44.75 \pm 9.48$ & $47.51 \pm \mid 1.71$ & 0.30 & $45.24 \pm|4.5|$ & $44.69 \pm 15.23$ & 0.85 \\
\hline LDL (mg/dL) & $121.63 \pm 42.01$ & || $2.5 \mid \pm 37.82$ & 0.34 & $120.06 \pm 38.88$ & $128.03 \pm 36.88$ & 0.43 \\
\hline WBC & $7.34 \pm 1.58$ & $8.23 \pm 1.52$ & 0.46 & $7.34 \pm 1.58$ & $7.5 \pm 1.78$ & 0.61 \\
\hline CK (mg/dL) & $79.96 \pm 49.86$ & $92.60 \pm 63.33$ & 0.43 & $93.95 \pm 11.21$ & $88.59 \pm 12.67$ & 0.78 \\
\hline
\end{tabular}

Abbreviations: SBP, systolic blood pressure; DBP, diastolic blood pressure; HDL, high-density lipoprotein; LDL, low-density lipoprotein; SD, standard deviation; WBC, white blood cells; CK, creatine kinase.

were not significantly different between the study and control groups $(P>0.05)$.

\section{Discussion}

In the present study, treatment with simvastatin markedly increased serum vaspin levels in patients with type 2 diabetes. The lipid-lowering effects of statins were also observed along with the increase in vaspin levels. This finding is consistent with those of other studies indicating that statins have an anti-inflammatory action beyond their cholesterol-lowering effect, and this has been reviewed elsewhere. ${ }^{17}$

Our results showing increased vaspin levels as a result of treatment with statins are consistent with the findings of Kadoglou et al. ${ }^{18}$ To our knowledge, this is the second

Table 3 Comparison of the mean difference in parameters at baseline and at end of study between study and control groups

\begin{tabular}{llll}
\hline Variable & \multicolumn{2}{l}{ Mean difference } & P value \\
\cline { 2 - 3 } & Study group & Control group & \\
\hline Vaspin $(\mathrm{pg} / \mathrm{mL})$ & 124.57 & 30.96 & 0.01 \\
SBP $(\mathrm{mmHg})$ & 2.12 & 0.70 & $<0.01$ \\
DBP $(\mathrm{mmHg})$ & 1.06 & 1.03 & 0.10 \\
Glucose $(\mathrm{mg} / \mathrm{dL})$ & 10.88 & 10.92 & 0.10 \\
Total cholesterol & 18.84 & 1.48 & $<0.01$ \\
(mg/dL) & & & \\
Triglycerides & 42.78 & 9.86 & $<0.01$ \\
(mg/dL) & & & \\
HDL $(\mathrm{mg} / \mathrm{dL})$ & 2.75 & 0.55 & $<0.01$ \\
LDL $(\mathrm{mg} / \mathrm{dL})$ & 9.12 & 7.96 & 0.03 \\
WBC & 0.89 & 0.16 & 0.64 \\
CK $(\mathrm{mg} / \mathrm{dL})$ & 12.64 & 5.36 & 0.42 \\
\hline Ab & &
\end{tabular}

Abbreviations: SBP, systolic blood pressure; DBP, diastolic blood pressure; HDL, high density lipoprotein; LDL, low density lipoprotein; WBC, white blood cells; CK, creatine kinase. prospective study demonstrating a relationship between statin therapy and serum vaspin levels. However, this study may be the first to show a positive correlation between statins and serum vaspin levels in patients with type 2 diabetes, in addition to a lipid-lowering effect. Such findings are in accordance with previous work showing that statins have a pleiotropic effect independent of their cholesterol-lowering

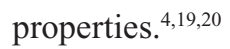

Vaspin is a novel adipokine that has shown insulinsensitizing effects in an animal model of type 2 diabetes. $^{21}$ Studies have also shown that vaspin has a protective effect against atherosclerosis and cardiovascular events. ${ }^{15}$ Vascular smooth muscle cell inflammation and migration play a crucial role in the development of atherosclerosis. ${ }^{22,23}$ Vaspin was shown to inhibit expression of intracellular adhesion molecule-1 induced by tumor necrosis factor- $\alpha$ by preventing generation of reactive oxygen species and subsequent activation of NF- $\kappa \mathrm{B}$ and protein kinase $\mathrm{C}$, thus inhibiting inflammatory states in vascular smooth muscle cells. ${ }^{24}$ Vaspin also inhibits platelet-derived growth factor-BB-induced vascular smooth cell migration by suppressing activation of reactive oxygen species-dependent p38/HSP27.25 Thus, the increment in vaspin may explain, in part, the beneficial effects seen with statin treatment.

This study has some limitations. For example, insulin resistance was not assayed for or correlated with the effect of statins on serum vaspin levels. However, this could be a project for future research to clarify the possible relationship between insulin sensitivity, vaspin levels, and the lipid-lowering effects of statins. Further, in this study, only vaspin levels were investigated, and studying the relationship between other important adipokines, such as visfatin or 
resistin, and the effects of statins represents another important future step. Finally, the change in systolic blood pressure that was observed in the study group is very unlikely to be clinically significant because the changes in blood pressure were only slight and within the normal range of blood pressure.

To our knowledge, no study has determined a minimal clinically significant change in vaspin levels. However, a number of previous studies have correlated changes in vaspin levels with various disease parameters, ${ }^{15,26-29}$ and have reported changes in vaspin that are similar in magnitude to these reported in the current study. In addition, the mechanism of the possible effect of statins on vaspin levels is not known. However, it is likely that statins, through their known anti-inflammatory and immunomodulatory properties, generally reduce proinflammatory marker levels. For example, C-reactive protein was shown previously to be an independent determinant of atorvastatin-induced vaspin changes in subjects with moderate cardiovascular risk. ${ }^{18}$ These findings could implicate molecules such as C-reactive protein in the changes seen in vaspin levels during atorvastatin therapy, but this needs further investigation in a patient population with type 2 diabetes.

In conclusion, simvastatin increases serum vaspin levels in patients with type 2 diabetes. This may represent a mechanism underlying the pleiotropic effects seen with statins. Further studies are required to confirm this hypothesis.

\section{Acknowledgment}

The study was funded by a grant to SA from the Deanship of Research, Jordan University of Science and Technology (58/2010).

\section{Disclosure}

The authors report no conflicts of interests in this work.

\section{References}

1. Kotlega D, Ciecwiez S, Turowska-Kowalska J, Nowacki P. Pathogenetic justification of statin use in ischaemic stroke prevention according to inflammatory theory in development of atherosclerosis. Neurol Neurochir Pol. 2012;46(2):176-183. Polish.

2. Wright RS, Murphy JG, Bybee KA, Kopecky SL, LaBlanche JM. Statin lipid-lowering therapy for acute myocardial infarction and unstable angina: efficacy and mechanism of benefit. Mayo Clin Proc. 2002;77(10):1085-1092.

3. Istvan ES. Structural mechanism for statin inhibition of 3-hydroxy-3methylglutaryl coenzyme A reductase. Am Heart J. 2002;144(Suppl 6): S27-S32.

4. Blanco-Colio LM, Tunon J, Martin-Ventura JL, Egido J. Antiinflammatory and immunomodulatory effects of statins. Kidney Int. 2003;63(1):12-23.
5. Musial J, Undas A, Gajewski P, Jankowski M, Sydor W, Szczeklik A. Anti-inflammatory effects of simvastatin in subjects with hypercholesterolemia. Int J Cardiol. 2001;77(2-3):247-253.

6. Lyngdoh T, Vollenweider P, Waeber G, Marques-Vidal P. Association of statins with inflammatory cytokines: a population-based Colaus study. Atherosclerosis. 2011;219(1):253-258.

7. Sparrow CP, Burton CA, Hernandez M, et al. Simvastatin has anti-inflammatory and antiatherosclerotic activities independent of plasma cholesterol lowering. Arterioscler Thromb Vasc Biol. 2001; 21(1):115-121.

8. Naples M, Federico LM, Xu E, Nelken J, Adeli K. Effect of rosuvastatin on insulin sensitivity in an animal model of insulin resistance: evidence for statin-induced hepatic insulin sensitization. Atherosclerosis. 2008;198(1):94-103.

9. Furuya DT, Poletto AC, Favaro RR, Martins JO, Zorn TM, Machado UF. Anti-inflammatory effect of atorvastatin ameliorates insulin resistance in monosodium glutamate-treated obese mice. Metabolism. 2010;59(3):395-399.

10. Kalupahana NS, Moustaid-Moussa N. The renin-angiotensin system: a link between obesity, inflammation and insulin resistance. Obes Rev. 2012;13(2):136-149.

11. Zeyda M, Stulnig TM. Obesity, inflammation, and insulin resistance a mini-review. Gerontology. 2009;55(4):379-386.

12. Goossens GH. The role of adipose tissue dysfunction in the pathogenesis of obesity-related insulin resistance. Physiol Behav. 2008;94(2):206-218.

13. Zhuang XF, Zhao MM, Weng CL, Sun NL. Adipocytokines: a bridge connecting obesity and insulin resistance. Med Hypotheses. 2009;73(6):981-985.

14. Kloting N, Berndt J, Kralisch S, et al. Vaspin gene expression in human adipose tissue: association with obesity and type 2 diabetes. Biochem Biophys Res Commun. 2006;339(1):430-436.

15. Kadoglou NP, Gkontopoulos A, Kapelouzou A, et al. Serum levels of vaspin and visfatin in patients with coronary artery disease - Kozani study. Clin Chim Acta. 2011;412(1-2):48-52.

16. Al-Azzam SI, Alzoubi KH, Khabour O, Alowidi A, Tawalbeh D. The prevalence and factors associated with aspirin resistance in patients premedicated with aspirin. Acta Cardiol. 2012;67(4):445-448.

17. Abeles AM, Pillinger MH. Statins as antiinflammatory and immunomodulatory agents: a future in rheumatologic therapy? Arthritis Rheum. 2006;54(2):393-407.

18. Kadoglou NP, Vrabas IS, Kapelouzou A, et al. Impact of atorvastatin on serum vaspin levels in hypercholesterolemic patients with moderate cardiovascular risk. Regul Pept. 2011;170(1-3):57-61.

19. Zhou Q, Liao JK. Pleiotropic effects of statins. Basic research and clinical perspectives. Circ J. 2010;74(5):818-826.

20. Pedersen TR. Pleiotropic effects of statins: evidence against benefits beyond LDL-cholesterol lowering. Am J Cardiovasc Drugs. 2010; 10 Suppl 1:10-17.

21. Hida K, Wada J, Eguchi J, et al. Visceral adipose tissue-derived serine protease inhibitor: a unique insulin-sensitizing adipocytokine in obesity. Proc Natl Acad Sci U SA. 2005;102(30):10610-10615.

22. Doran AC, Meller N, McNamara CA. Role of smooth muscle cells in the initiation and early progression of atherosclerosis. Arterioscler Thromb Vasc Biol. 2008;28(5):812-819.

23. Ross R. Atherosclerosis - an inflammatory disease. $N$ Engl J Med. 1999;340(2):115-126.

24. Phalitakul S, Okada M, Hara Y, Yamawaki H. Vaspin prevents TNF-alpha-induced intracellular adhesion molecule-1 via inhibiting reactive oxygen species-dependent NF-kappaB and PKCtheta activation in cultured rat vascular smooth muscle cells. Pharmacol Res. 2011;64(5):493-500.

25. Phalitakul S, Okada M, Hara Y, Yamawaki H. A novel adipocytokine, vaspin inhibits platelet-derived growth factor-BB-induced migration of vascular smooth muscle cells. Biochem Biophys Res Commun. 2012;423(4):844-849. 
26. Kobat MA, Celik A, Balin M, et al. The investigation of serum vaspin level in atherosclerotic coronary artery disease. J Clin Med Res. 2012; 4(2):110-113.

27. Cantarini L, Simonini G, Fioravanti A, et al. Circulating levels of the adipokines vaspin and omentin in patients with juvenile idiopathic arthritis, and relation to disease activity. Clin Exp Rheumatol. 2011;29(6): 1044-1048.
28. Yilmaz Y, Kurt R, Gurdal A, et al. Circulating vaspin levels and epicardial adipose tissue thickness are associated with impaired coronary flow reserve in patients with nonalcoholic fatty liver disease. Atherosclerosis. 2011;217(1):125-129.

29. Kukla M, Zwirska-Korczala K, Hartleb M, et al. Serum chemerin and vaspin in non-alcoholic fatty liver disease. Scand $J$ Gastroenterol. 2010;45(2):235-242.

\section{Publish your work in this journal}

Clinical Pharmacology: Advances and Applications is an international, peer-reviewed, open access journal publishing original research, reports, reviews and commentaries on all areas of drug experience in humans. The manuscript management system is completely online and includes a very quick and fair peer-review system, which is all easy to use.

Submit your manuscript here: http://www.dovepress.com/clinical-pharmacology-advances-and-applications-journal
Visit http://www.dovepress.com/testimonials.php to read real quotes from published authors. 